\title{
Uso de esponja cirúrgica para curativo compressivo de enxerto cutâneo*
}

\section{Surgical sponge as a pressure dressing for skin grafts*}

Maurício Zanini ${ }^{1}$

Carlos D' Apparecida Santos Machado Filho

Fábio Timoner $^{3}$

\begin{abstract}
Resumo: O enxerto cutâneo é um modo efetivo para restaurar feridas. O curativo compressivo é importante para a vitalidade do enxerto. Os autores observaram que o uso de esponja cirúrgica como curativo compressivo em enxertos cutâneos é factível e aconselhável.

Palavras-chave: cirurgia; sobrevivência de enxerto; transplante de pele.

Summary: Cutaneous graft is an effective way to treat wounds. A pressure dressing is important for the vitality of such grafts. We have observed that the use of surgical sponge as a pressure dressing on cutaneous grafts is feasible and recommend its use.

Keywords: surgery; graft survival; skin transplantation.
\end{abstract}

O enxerto cutâneo é um modo efetivo para restaurar ou reparar uma ferida, cirúrgica ou não, desde que preservados os princípios de vascularidade, antissepsia e hemostasia. Trata-se de segmento de epiderme e derme de espessura variável obtido cirurgicamente de uma área doadora a fim de ser implantado numa área receptora. ${ }^{1}$ A quantidade de derme determinará a espessura do enxerto. Em geral, quanto mais fino o enxerto maior seu potencial de vida e menor a qualidade estética. ${ }^{2}$

Após o enxerto ser fixado na área receptora é importante estabelecer um curativo compressivo. Esse curativo é de particular importância para enxertos de grande dimensão e espessura. Entretanto, existem algumas situações em que o curativo compressivo não é aconselhado, como em feridas infectadas ou localizadas em áreas que potencialmente produzem grande quantidade de linfa, como a região inguinal.'

Sabendo-se que o enxerto não apresenta pedículo vascular, o objetivo do curativo compressivo é otimizar o contato do enxerto com o leito da ferida e permitir adequada angiogênese. Em intervalo de três a cinco dias começam
Cutaneous graft is an effective way to restore or to repair a wound, whether surgical or not, provided that one observes the principles of vascularity, antisepsis and hemostasia. The graft is a segment of epidermis and dermis with variable thickness obtained surgically in order to be implanted in a recipient area. ${ }^{.}$The quantity of dermis determines the thickness of the graft. In general, the thinner the graft the greater its potential for survival but lower its esthetic quality. ${ }^{2}$

After the graft is fastened into the recipient area it is important to provide a pressure dressing. This dressing is of particular importance for grafts with major dimensions and thickness. However, there are some situations in which a pressure dressing is not indicated, as in infected wounds or when located in areas that potentially produce great amounts of lymph, such as the inguinal region. ${ }^{l}$

Since the graft does not present a vascular pedicle, the objective of the pressure dressing is to optimize the contact of the graft with the wound bed and to allow appropriate angiogenesis. After three to five days, vascular communications begin to appear with the transplanted skin.

Recebido em 22.05.2003. / Received in May, $22^{\text {nd }}$ of 2003.

Aprovado pelo Conselho Consultivo e aceito para publicação em 23.11.2003. / Approved by the Consultive Council and accepted for publication in November, $23^{\text {rd }}$ of 2003.

* Trabalho realizado no Departamento de Dermatologia da Faculdade de Medicina da Fundação do ABC, Santo André, SP, Brasil. / Work done at the Dermatology Dept., School of Medicine, ABC Foundation, Santo André, SP, Brazil

Membro efetivo da Sociedade Brasileira de Dermatologia, residente em Cirurgia Dermatológica da disciplina de Dermatologia da Faculdade de Medicina do ABC. / Effective Member of the Brazilian Society of Dermatology, Surgical Dermatology Resident, Dermatology Dept., School of Medicine, ABC Foundation.

2 Doutor em Medicina, membro efetivo da Sociedade Brasileira de Dermatologia, chefe interino da disciplina de Dermatologia da Faculdade de Medicina do ABC. / Ph.D. in Medicine, Effective Member of the Brazilian Society of Dermatology, Acting Head of the Dermatology Dept., School of Medicine, ABC Foundation.

Membro efetivo da Sociedade Brasileira de Dermatologia, professor auxiliar de Cirurgia Dermatológica da disciplina de Dermatologia da Faculdade de Medicina do ABC. / Effective Member of the Brazilian Society of Dermatology, Auxiliary Professor of Surgical Dermatology, Dermatology Dept., School of Medicine, ABC Foundation. 
a surgir comunicações vasculares com a pele transplantada. O curativo compressivo reduzirá a possibilidade de deslocamentos que comprometeriam essa comunicação. Além do mais, possibilitará menor ocorrência de hematoma e seroma, eventos que habitualmente conduzem à perda de vitalidade e, por conseqüência, à falência do enxerto. ${ }^{2}$

A pressão adequada sobre o enxerto varia de 15 a $30 \mathrm{mmHg}$. Pouca pressão pode produzir contato inadequado e permitir a formação de coleções líquidas. Muita pressão pode comprimir os capilares e determinar necrose do enxerto. ${ }^{3}$ A compressão pode ser obtida com alguns materiais como gazes cirúrgicas, algodão umedecido e esponja. A técnica habitual consiste em suturar um bolo de gazes sobre o enxerto. Entre o enxerto e o curativo é comum aplicar-se gaze não aderente com pomada antibiótica ou vaselina. ${ }^{1}$

O curativo compressivo é deixado por período que varia de sete a 14 dias desde que não haja sinais de infecção, sangramento ou perda da imobilização. Caso contrário, o curativo deve ser retirado, e o enxerto, examinado. Por exemplo, coleção sangüínea, purulenta ou serosa deve ser evacuada. O curativo pode ser recolocado após a correção desses eventos adversos descritos., ${ }^{2,4}$

O método mais amplamente usado de fixação do curativo é a sutura trançada superior ao material compressivo (Figura 1). Vários materiais podem ser usados na compressão, como gaze, algodão, discos plásticos, moldes de cera, etc. A idéia do uso de esponja ou espuma surgiu em 1929 com Blair e Brown, que afirmaram ser a esponja o mais prático distribuidor de pressão. ${ }^{1}$

No Serviço de Cirurgia Dermatológica são realizados enxertos cutâneos de dimensão e espessura variáveis que foram submetidos ao curativo compressivo com esponja cirúrgica usada na escovação das mãos. A escova-esponja já vem esterilizada por radiação gama-Cobalto 60 (Figura 2).

A técnica realizada é descrita a seguir. O enxerto é suturado com fio mononáilon 6.0 com pontos separados a fim de estabilizar sua localização. Suturas adicionais são

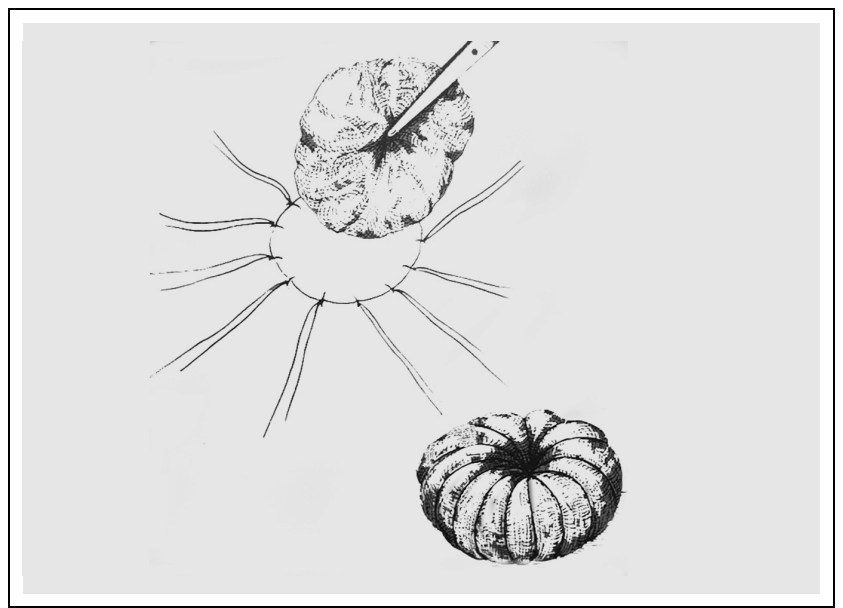

Figura 1: Técnica habitual do curativo compressivo de enxerto cutâneo usando chumaço de gaze. / Figure 1: Usual technique for pressure dressing on cutaneous grafts using a gauze wad.
The pressure dressing serves to reduce the possibility of a displacement that would compromise this communication. Additionally, it enables a reduced occurrence of bruising and seroma, events that commonly lead to a loss of vitality and consequently a failure of the graft. ${ }^{2}$

The appropriate pressure on the graft varies from 15 to $30 \mathrm{mmHg}$. Too little pressure can result in inadequate contact and allow the formation of liquid collections. Too much pressure can compress the capillaries and lead to necrosis of the graft. ${ }^{3}$ The pressure can be obtained with material such as surgical gauze, moistened cotton and sponge. The usual technique consists of suturing a wad of gauzes over the graft. A non-adherent gauze is commonly applied between the graft and the curative, together with antibiotic ointment or Vaseline.

The pressure dressing is left in position for a period that varies from seven to 14 days, provided there are no signs of infection, bleeding or loss of immobilization. Otherwise, the curative should be removed and the graft duly examined. For instance, bloody, purulent or serous collections should be evacuated. A new dressing can be applied after correcting such adverse events. ${ }^{2,4}$

The most widely used method for holding the curative in place is braided suture over the pressurizing material (Figure 1). Several materials can be used to provide pressure, for examples: gauze, cotton, plastic disks, wax molds, etc. The idea of using sponge or foam was first described in 1929 by Blair and Brown, who affirmed that the sponge is the most practical distributor of pressure. ${ }^{l}$

In a Dermatological Surgery Service, cutaneous grafts are performed with varying dimensions and thickness and are then subjected to pressure dressings with a surgical sponge, as used for scrubbing hands. The sponge-brush having first been sterilized by cobalt-60 gamma-radiation (Figure 2).

The technique is performed as follows. The graft is sutured with monofilament nylon thread (6.0) with separate stitches in order to stabilize its location. Three to six addi-

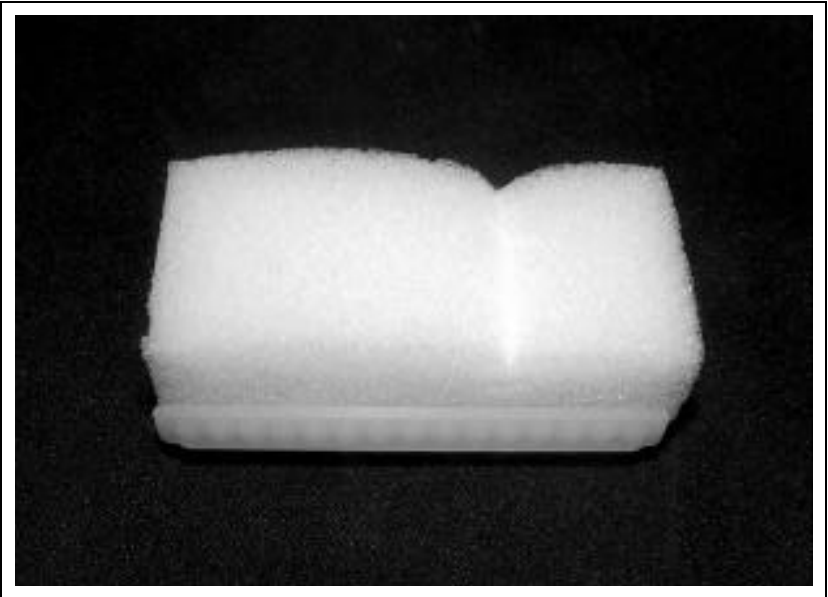

Figura 2: Conjunto escova-esponja cirúrgica Figure 2: Surgical brush-sponge 


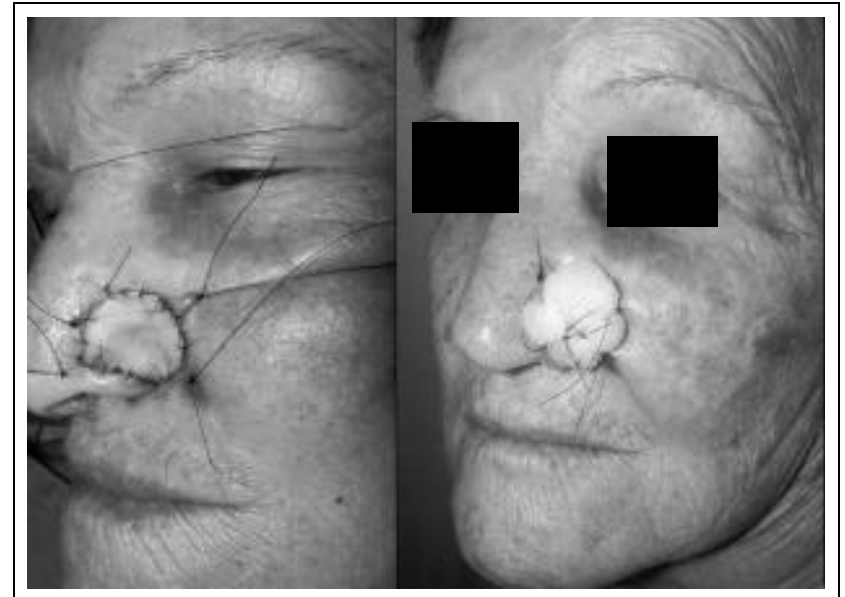

Figura 3: APaciente com carcinoma basocelular nasal submetido a enxerto cutâneo. À direita, 2o PO com curativo compressivo de esponja. / Figure 3: Patient with nasal basal cell carcinoma submitted to cutaneous graft. On the right, postoperative day 2 with sponge pressure dressing.

realizadas nos pontos cardinais em número que varia de três a seis com fio mononáilon 5.0 a fim de fixar o curativo compressivo (Figura 3). O preparo da esponja compressiva consiste em dois passos. Primeiro, destaca-se a esponja da escova, o que é um processo muito simples; segundo, com uma tesoura ou lâmina de bisturi, reduz-se a espessura da esponja para 0,8 ou $1 \mathrm{~cm}$. Deixa-se uma extensão projetada para exceder em torno de $0,5 \mathrm{~cm}$ a margem do enxerto. Antes de iniciar a colocação do curativo, é preciso certificar-se da ausência de sangramento e da correta disposição do enxerto. Em seguida, coloca-se pomada antibiótica à base de gentamicina, bacitracina ou neomicina. Sobre a pomada, coloca-se a esponja e a fixamos com as suturas adicionais. A sutura deve exercer adequada tensão para manter imobilizado o enxerto. O uso de fita cirúrgica adesiva (micropore $囚)$ sobre o curativo é permitido e reduz o desconforto estético do paciente. A reavaliação deve ser feita em prazo que pode variar de 24 a 72 horas, a fim de observar qualquer complicação cirúrgica. $\mathrm{O}$ curativo é retirado, e as suturas, removidas em sete dias da face e em duas semanas de outros locais (Figura 4).

A realização de curativo compressivo para enxerto cutâneo com esponja e materiais similares, embora não seja procedimento de uso recente, ${ }^{1,5,6}$ é freqüentemente esquecido no Brasil. O uso da esponja oferece muitas vantagens, a saber: baixo custo, adequada proteção do enxerto, fácil técnica de realização, moldável em diferentes formas, pressão uniformemente distribuída, retirada fácil e redução do desconforto pós-operatório do paciente. Quando comparada com os cuidados pós-operatórios da técnica habitual com gaze ou algodão, a esponja mostra-se mais prática por geralmente não aderir ao enxerto e, quando isso ocorre, poder ser retirada com mais facilidade. Nos casos em que haja necessidade de examinar o enxerto, tanto a retirada quanto a recolocação da

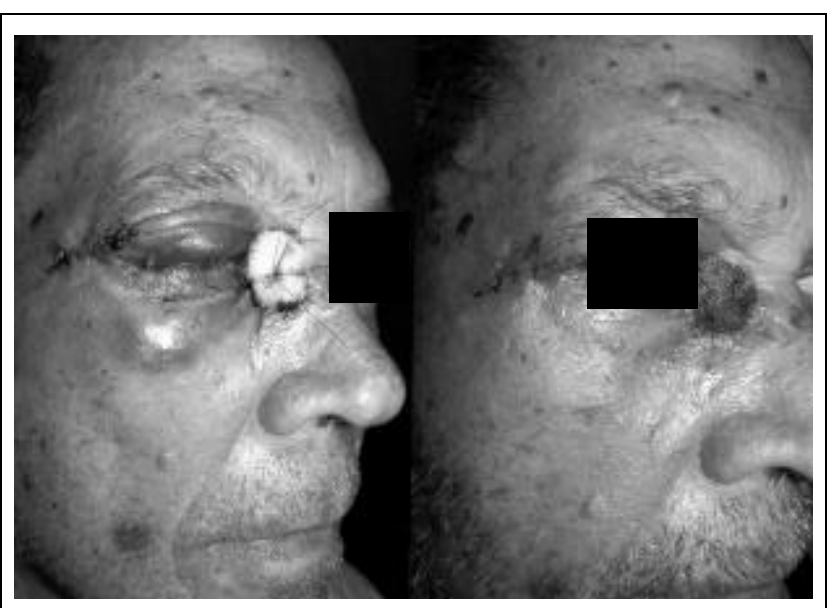

Figura 4: Paciente submetido a enxerto cutâneo com curativo compressivo com esponja. À direita, 7o PO com a retirada do curativo. Observe a coloração sempre desejada do enxerto, indicando sua vitalidade. / Figure 4: Patient submitted to cutaneous graft with a sponge pressure dressing. On the right, postoperative day 7 following removal of the dressing. Note the appropriate coloration of the graft, indicating its vitality.

tional sutures are then made at the cardinal points with monofilament nylon thread (5.0) in order to fix the pressure dressing (Figure 3). The preparation of the pressurizing sponge consists of two steps: firstly, the sponge is removed from the brush, which is a very simple process; then with a pair of scissors or bistoury, the thickness of the sponge is reduced to $0.8-1.0 \mathrm{~cm}$. It is then cut oversize to allow an overlap of approximately $0.5 \mathrm{~cm}$ along the margin of the graft. Before placing the dressing in position, it is necessary to certify the absence of bleeding and proper arrangement of the graft and apply antibiotic ointment with a gentamycin, bacitracin or neomycin base. The sponge is then placed over the ointment and fixed with the additional sutures. The suture should provide enough tension to maintain the graft immobilized. The use of adhesive surgical tape (micropore ${ }^{\circledR)}$ over the dressing is an option that reduces the patient's aesthetic discomfort. An inspection should be made within 24 to 72 hours, in order to detect any surgical complication. The dressing and sutures are removed after seven days from the face and after two weeks from other areas (Figure 4).

The application of a pressure dressing onto cutaneous grafts using a sponge or similar material, although not a recent procedure, ${ }^{1,5,6}$ is frequently overlooked in Brazil. The use of a sponge offers many advantages, especially: low cost, appropriate protection of the graft, easy technique, it can be molded into different forms, the pressure is evenly distributed, it is easily removed and reduces the patient's postoperative discomfort. When compared to the postoperative care of the usual technique with gauze or cotton, the sponge has proven to be more practicable as it does not usually adhere to the graft and, when this happens, it can be removed with greater ease. Whenever it is necessary to examine the graft, both the removal and replacement 
esponja são mais fáceis do que com outras técnicas. A referência à redução do desconforto do paciente significa que os eventuais sangramentos que ocorrem no pós-operatório tendem a ser absorvidos completamente pela esponja.

O curativo ideal apresenta importantes aspectos como ventilação, absorção líquida, proteção, aplicação de pressão e método de barreira contra contaminantes. ${ }^{7} \mathrm{~A}$ esponja enquadra-se nessa definição. Com base no disposto, pode-se concluir que o uso de esponja cirúrgica no curativo compressivo de enxertos cutâneos é factível e aconselhável.

\section{REFERÊNCIAS / REFERENCES}

1.Vasconez LO, Vasconez HC. Plastic \& reconstructive surgery. In: Way LW. Surgical diagnosis and treatment. Connecticut: Appleton \& Lange Pubs., 1994:1130-4.

2. Leffell DJ. Split-thickness skin grafts. In: Robinson JK, Arndt KA, LeBoit PE, Wintroub BU. Atlas of cutaneous surgery. Philadelphia: W.B. Saunders Co., 1996:149-56.

3. Larson PO. Foam-Rubber sents for skin grafts. J Dermatol Surg Oncol 1990; 16:851-4.

4. Wheeland RG. Skin grafts. In: Roenigk RK, Roenigk HH Jr, eds. Dermatologic surgery: principles and pratice. New York: Marcel Dekker, 1989:323-45.

5. Mehta HK. A new method of full-thickness skin graft fixation. Br J Plast Surg 1985; 38:125-8.

6. Shively RE, Northington JW, Williamson GB, Gum RA. A simple skin graft dressing allowing early graft inspection. Ann Plast Surg 1981; 7: 334-5. of the sponge are easier than with other techniques. With regard to the reduction in discomfort for the patient, this is due to the fact that occasional bleeding during the postoperative tends to be completely absorbed by the sponge.

The ideal dressing should present important aspects such as providing ventilation, absorption of liquids, application of pressure and a barrier against contaminants. ${ }^{7}$ The sponge meets these requirements. Based on the above, once can conclude that the use of surgical sponge as a pressure dressing for skin grafts is a feasible and recommendable practice.

7. Smith SL, Belmont JM, Casparian JM. Analysis of pressure achieved by various materials used for pressure dressings. Dermatol Surg 1999; 25(12): 931-4.

\author{
ENDEREÇO PARA CORRESPONDÊNCIA: / MAILING ADDRESS: \\ Dr. Maurício Zanini \\ Rua Vicente de Carvalbo, 198 \\ 09060-590 Santo André SP \\ Tel.: (11) 4992-7724 \\ E-mail:drzanini@terra.com.br
}

